\title{
ICT- based Material Development for History Subject of 3rd Grade Primary School of Jogja Patriae Academy (English Spesific Purpose)
}

\author{
${ }^{1}$ Emilia Widuri, ${ }^{2}$ Ashadi \\ Emiliawiduri1@gmail.com, ashadi@uny.ac.id \\ ${ }^{1}$ Graduate Program of English Education, Yogyakarta State University, ${ }^{2}$ English Education Department \\ Yogyakarta State University
}

\begin{abstract}
Materials used in classrooms play a crucial role in facilitating teaching and learning process of English. This research paper consists of needs analysis process and materials development process with all its steps. The research took place in JPA primary school because there is no team for developing materials, media, and syllabus. Teachers design the lesson plans and learning materials based on their creativity without any consideration of the students' needs. The researcher conducted needs analysis research to gain an understanding of the students' lacks, wants, and necessities. Reading and Grammar teachers were interviewed during the research in order to corroborate the collected information earned from a distributed questionnaire and documents analysis. The needs analysis result revealed that it is urgently needed to develop learning material for teaching and learning history subject. The researcher used Content and Language Integrated Learning approach (CLIL) and supported by ICT tools to develop learning activities for teaching and learning history by using English as a language of instruction. The current paper reports on the project process with all of its steps including the developed activities result as a learning material.
\end{abstract}

Keywords:Material Development; English for Children; English Specific Purpose (ESP); ICT based Learning Material; Content and Language Integrated Learning approach (CLIL).

\section{Introduction}

The materials used in classrooms play a crucial role in facilitating teaching and learning process. They can significantly increase the students' achievement by supporting their learning; moreover, materials add an important structure to plan and deliver lesson instructions. Thus, a significant part of attention should be given to the area of materials development in order to ensure that students are fully in exposure to effective and comprehensive input. Harsono[1] claims that by having the objectives of the teaching/learning or being familiar with the needs of the learners, the teachers can develop their own materials for the learners to achieve the objectives or to fulfil the needs ofthe learners. The learners' needs are the most important consideration that should be the rationale behind selecting and developing materials. Tomlinson[2] states that materials need to be written in such a way that the teacher can make use of them as a resource and not have to follow them as a script. Hence, it is possible for teachers to adapt or adopt learning materials based on their students' needs and characteristics.

Brewster[3], emphasize that children at four until twelve do not have specific foreign language needs, although some may be under the pressure which come usually from their parents or school system to pass English language examinations, but not come from 
themselves. Thus, there are three important theories about children development summed up byTomlinson[2], which are important to be considered by teachers when developing learning material. Firstly, young learners are developing thinkers; they think actively and love to explore new things around them. Secondly, young learners are able to learn from the adults and from their peers. Lastly, young learners are able to take responsibilities and can be reliable for classroom activities and routines.

In terms of teaching reading as proposed by Brown[4] teachers need to consider students' motivation that can be triggered by taking into consideration their age and their level of language competence in L1 and L2, adopting activities that are within their interests, designing meaningful tasks, integrating fun, play and imagination in teaching program, and being prepared to act also for keeping the affective filter low. Reading activities should cover pre, while, and post reading phases to activate the students' schemata and motivate them to learn effectively.

CLIL is an acronym for Content and Language Integrated Learning. It is an approach to teach the content of curricular subjects through a medium of non-native language. In CLIL, learners gain knowledge and understanding of the curricular subject while simultaneously learning and using the target language[2]. CLIL is designed to support several key needs of young learners' brain based on their characteristics such as the need to make meaning of their learning. In this case, the young learners' desires are to find the relevance to their own lives. Thus, CLIL accommodate it by integration of content and language into curriculum. Coyle, D., Hood, P., \& Marsh, D[5] mention that CLIL has been defined as a dual focused educational approach in which an additional language is used for teaching and learning of both content and language, thus it involves teaching another curriculum subject or aspects of another subject through a second language which is relevant with young learners' life.

This paper is a way for helping English teachers particularly in material development as there is no team for creating materials, media, syllabus in the research site. Teachers design the lesson plans based on their creativity to handle the lesson. Therefore, the school need to be provided with learning activities. The subjects of this research are the third-grade studentsof JPA because they are already able to read and write well and have more free time rather than students from higher level classes who would prepare for the national examination. JPA is semi home schooling under the care of the Religion Ministry, which students attend only three days' school in a week. It is considered as a classical Christian school from kindergarten to primary school. The uniqueness of this school lies on the fact that all the subjects from kindergarten to primary school are delivered in English. The curriculum and materials used in this school are adapted from both national and classical curriculums. The national curriculum is used to pass the national examination and the classical curriculum consists of biblical, linguistics, history, science, and mathematics. In addition, course-books from Singapore are used for teaching grammar, mathematics, and science. Meanwhile, the course-books from the United States of America are used for reading comprehension and history of the world. To sum up, this paper mainly aims to find out information about students' needs in JPA primary school; to develop appropriate learning activities based on students' needs; to develop appropriate media that support students' needs in teaching and learning process is packed as a learning material.

\section{Research Method}

The current research utilizes research and development (RND). The objective of this research is to develop teaching and learning materials for primary school students of the third grade in JPA School. These materials are developed based on the students' needs. This research is categorized as an Educational Research and Development (R\&D). Gall, Gall and 
Borg[6] state that "Educational R\&D is an industry-based development model in which the findings of research are used to design new products and procedures, which are systematically field-tested, evaluated, and refined to meet the specified criteria of effectiveness, quality or similar standards". The result of this study will be used for developing teaching and learning materials based on Content and Language Integrated Learning approach (CLIL) and supported with ICT tools.

The activities of this project are based on the CLIL(Content and Language Integrated Learning) approach and supported with ICT tools to make it more interesting. CLIL is an approach to teach the content of curricular subjects through the medium of non-native language. In a CLIL, learners gain knowledge and understanding of the curricular subject while simultaneously learning and using the target language [4]. CLIL principles and foundations will be considered in the developed lesson plans and activities to provide the students with interactive activities to develop their English ability and enhance their understanding in history. In developing lesson plan the researcher also use ICT tools to make it more interesting.Information Technology dan Communication Technology, as stated in UNESCO[7] is: Information technology is the term used to describe the items of equipment (hardware) and computer program (software) that allow us to access, store, organize, manipulate, and present information by electronic means. Communication technology is term used to describe telecommunication equipment, through which information can be sought and accessed. Academically, ICT not emphasized sophisticated in computer and internet only, but also conventionally, such as Overhead Transparency (OHT)/ Overhead Projector (OHP), office power point (PPT), video, sound slides, radio and television. In this research, the ICT based is still in conventionally part.

\section{Finding and Discussion}

The first step in developing materials or courses is conducting the needs analysis in order to meet the appropriateness to the necessities, goals and wants of the learners and the learning process[2]. In this research, the needs analysis was conducted with several instruments that include interview, observation checklist and theoretical study to compare the ideal of learning process and the real situation to know what is the problems that should be solved in the course project. Procedure of Collecting Needs Analysis are: (i) interviewing the Headmaster of the school and asking for permission, (ii) Designing observation checklist and interview questions for teachers, (iii) Conducting observation in history class, (iv) interviewing the teachers. In the table 1.presents the observation results in comparison to what is stated in theory of good class management and atmosphere for young learners by Neville[8]:

Table.1 The observation results in comparison to theory of good class management and atmosphere for young learners:

Theories of young learners (Neville, 1991): 
a. An ideal teacher

To be an ideal teacher does not mean being able to do the entire task, and to be perfect. Teacher comes to the job with their personalities already formed, but there are abilities and attitudes that can be learnt and worked on.

1. Helping children feel secured

Once children feel secured and content in the classroom, they are encouraged to become independent, adventures, and autonomous learners in the learning of language.

2. Cooperation not competition

Create an atmosphere of involvement and togetherness, its conditions are much more effective. Most of us enjoy the feeling of belonging and this is particularly true of young children. Group the children whenever possible. This does not mean they have to work in-group all the time, but, most children like to have other children around them, and sitting with others encourage cooperation.

After doing a classroom observation, the researcher concluded that the history classroom needed more interactions among the teacher and the students because young learners need to be involved in communicative language learning activities and use the language with their classmates. In addition, the teacher did not use the ICT tools to support the students learning and the teaching process. Another aspect that should be given a significant attention is the integration of Information and Communication Technology (ICT) tools in the classroom. Based on the observation, the researcher discovered that the teacher did not integrate ICT tools in teaching history to her students. The way the teacher used to teach was asking the students to read several paragraphs of a text, and then the teacher asked them questions about the material. The mentioned method of teaching was quiet boring for young learners who need to move and interact with each other.

To solve the problems mentioned above, the first step that should be done is designing a reading lesson plan in history subject that including instructions for teachers. The lesson plan development should be made based on the needs analysis of the teacher and students also. Several ICT tools could be integrated in the lesson plan such as intellectual games that can help the students acquire new vocabulary from the text. Another ICT tool that could be used was the Office PowerPoint(PPT). Teacher could use PPT to show his students pictures concerning the topic of the text. Moreover, the silent reading is a very useful strategy that can be used to facilitate the learners understanding about the text content, while in the observed classroom, silent reading was not included.

\subsection{Steps in developing learning material: Authentic and Integrated Activities/Game CLIL-based Material Evaluation and ICT tools integration}

After analyzing the findings of the needs analysis process, the criteria proposed by Tomlinson[2] as cited-in, has been chosen to be the general format of the activities. The 
mentioned criteria consist of five stages. The first is readiness activities or pre-reading activities that aim to stimulate the relevant schemata to the topic. This kind of activities address the learners' prior knowledge to be matched with the input given by the teacher such as pictures or words related to the text. By relating the input with the background knowledge, learners predict what approximately the text talks about.

The next stage in Tomlinson framework is experimental activities or while-reading activities that facilitate the students to experiment the text by doing activities while reading it. In the current activities, this stage is applied through communicative and collaborative reading activities. These activities make the reading more interesting for the learners especially the kinesthetic learners, because they read the text through moving and free mobile sitting reading activities. The most important techniques on reading comprehension were considered when developing the activities such as scanning and identifying specific information in the text.

The next important step is ICT tools integration. In this step, the researcher focused on integrating ICT tools in the developed material effectively. She included some videos and pictures to activate the students' background knowledge that meet their needs. Some of the activities included ICT tools that met the preferences and learning styles. The researcher also used coloring PPT and gave back sound music to make the reading activity more interesting.

The last section of the activities applies all the three last stages in Tomlinson framework. In this section, students represent their understanding of the text by producing output .The craft activity is included as fun activity to enhance the students' creativity as it was required from the teacher during the needs' analysis interview. After providing a brief description of the activities and the reasons behind their design, the procedure of trying them out can be described in the following way:

The try-out of the materials and activities consisted of two meetings. The learning process is divided into three sections, the first is pre-reading activity that consisted of guessing from picture activity and pair discussion activity. The second section consists of silent reading, writing the difficult words, guessing from the sentences, watching video and role-playing. While the third was post teachingactivity consisting of retelling the text, exercise and giving homework. Before trying-out the materials and activities, the researcher sent the draft to the teacher and asked for her feedback and her willingness to apply the activities. The teacher gave many feedback and then both sides agreed with some compromises.

On the first trying-out day, the teacher did the activities based on the compromised draft but she did not do all the activities. The teacher did not do the guessing sentence but she gave the meaning directly to the students and role play because it took long time only for reading. As the researcher' observation in the first try-out, the teacher still not be able to maintain the students' concentration and the students were still distracted with their own activities. It is possibly caused by the less-attracted activities in this meeting and also the teacher seemed to waste time more on her explanation. Therefore, for the second try-out, the fun and fully students' involvement activity were needed to make students learn effectively.

The next step that followed the second section of activities development was getting the teacher's feedback. According to the teacher, the language used in the activities and their level of difficulty are suitable for the learners' level. In addition, the teacher expressed her satisfaction towards the activities sequencing and the materials used in them such as pictures and handcrafting tools. The teacher emphasized the time constraints as one of the obstacles that can restrict the process of applying the activities effectively. She mentioned that the duration of the activities is not sufficient especially for the craft activity. The teacher selected three activities from six to be tried-out by herself in the classroom, the activities are: prediction tasks, matching activities, and sentences writing activities. 
On the second try out day, the first activity that was the prediction task. She wrote four words from the text and asked the students to predict what the text was about. The students spent around three minutes giving several predictions, some of them were close to the topic of the text while some were not. With the help of the teacher, the students ended-up with the closest prediction that was "David, the king of Israel", while the correct answer is "Davidic kingdom". This activity made the students more active and involved in the classroom, but it took longer time than what the activity researcher predicted, maybe because the level of students as young learners did not make them predict the accurate answer quickly. In addition, the unfamiliarity of the students with the prediction tasks may make them struggles. As an alternative, pictures and audios maybe will facilitate the learners to predict the answer quickly.

The second activity in the try-out was While-Reading Activity: (Game) Fairy Tale Rebus. The researcher chose a game because games have many advantages. Games are a welcome break from the usual routine of the language class, games are motivating and challenging, learning a language requires a great endeavors and games help students to make and sustain the effort of learning. Moreover, games provide language practice in the various skill of speaking, writing, listening and reading. Games also encourage students to interact and communicate, games create a meaningful context for language use. In this case, the games aimed at determining the students' comprehension in terms of learning the story, and to ensure their competency and proficiency of using and understanding vocabulary based on the story whether it is paraphrasing or original text. First, teacher gave students the opportunity to read the text of Davidic Kingdom by themselves. Then, teacher explained and described the events mentioned in the text once again, also portrayed in each of the characters of the story. This made students more interpretative in the text. Using different vocabulary to explain and using gesture and body language to describe and portray the characters would make students more interested in. After that, the teacher moved the learners to the game section after knowing all the characters and the vocabulary in the text. This game was called Fairy Tale Rebus. In this game, students had to replace words or characters in the story with pictures. The game aimed at stimulating the students' memorizing and making them much more motivated and excited. Guessing the characters and words that are missed in the sheet of papers will make them trying to find the appropriate word. This enhances the students' capability of vocabulary knowledge and also can help them by making reading fun. This game took around 15 minutes to be completed. After that, the teacher checked the mistakes of each group, and happily only a few mistakes were found. This indicated that students have deep understanding in terms of the text, vocabulary, and the characters.

The third activity was matching activity. After reading the text, the students were asked to match the pictures with the words. This activity aimed to develop the learners' vocabulary knowledge and enhance their intellectual ability in remembering and matching the word's form with its meaning. Some of the students said that the activity seems to be very easy, but after doing it, three of the four students did some mistakes. The activity did not take a long time from the students to finish it. The mistakes done by the students can be inferred due to their different learning styles since the activity is appropriate for visual learning style.

\subsection{Material Evaluation}

Wijaya[9] claims that the criteria and the key questions central for setting up a material evaluation scheme partly depends on "the swings of linguistic fashion". Rea-Dickens (cited in $\mathrm{Li}[10])$ summarizes three kinds of evaluation: (1) pre-use evaluation; (2) in-use evaluation; and (3) post-use evaluation, measured in terms of learners' performance. She advocates giving more attention to in-use and post-use evaluation. In-use and post-use evaluations are important in establishing how successful learning materials are. This research evaluation carried out in 
in-used and post-used evaluation. In-used evaluation carried after the first try-out for the development of material on April 29 $9^{\text {th }} 2017$. While the post-used evaluation was carried out after the second try-out on May $6^{\text {th }} 2017$.

In the current research, the researcher interviewed the head master who attended the tryout process to get her feedback and opinions about the developed materials and its try-out. The head master stated that the activities are suitable for the elementary school students. The technology also was well integrated in the activities. The learning styles are also fully addressed in the activities. Speaking, reading, and writing are well integrated in the activities. The time given for each activity is enough to fulfill the learning objectives except for game like role playing that takes a longer time. Fun learning is well applied in the activities. The focus was given both history learning and language use. Vocabulary learning strategies for historical purposes was considered. The goal of teaching history (the moral values and character education) were applied in the activities. The developed activities are creative. The designed activities are sequenced systematically to meet the students' needs. The aspect that she mostly liked in these activities is when children are associated to the topic by learning through visual images (such as sticking pictures to complete the story). The head master also said that the activity still lack of "fun facts" about the topic they were learning that can be applied in the activities for example a question about: Did you know that 100 men were needed to lift a block for pyramid stone?

\section{Conclusion}

It can be concluded that the developed learning materials after being tried-out twice and being improved after the first try-out based on the teachers' feedback are suitable for the learners' level and successfully met their needs in terms of learning history through the use of English as a language of instruction. It is highly recommended for teachers to develop the learning materials they use in the classrooms systematically by taking into account the appropriate approach that can make the learning process more effective. In addition, due to the nature of young learners as active and sometimes critical learners, it is highly recommended for teachers and material developers to integrate ICT tools as media and interesting games when teaching young learners to motivate them and stimulate their attention. In addition, in the current research, the way the researcher analyzed the students' needs and developed material based on them must be followed by teachers when attempting to develop material. Developing learning materials in a random and non-systematic way will lead to less effective learning and teaching process.

Acknowledgement. I acknowledge this work to all the people who supported me through my education journey.

\section{References}

[1] Y. H. Harsono, "Material Development for Specific Purposes," TEFLIN J., vol. 8(2), pp. 169-179, 2007.

[2] B. Tomlinson, Principles and procedures of materials development, In N. Harwood (ed.) Materials in ELT: Theory and Practice. Cambridge: Cambridge University Press, 2010.

[3] B. et. al., The Primary English Teacher's Guide. England: Pearson Education Limited, 2004.

[4] Brown, "A Comparison of Three Learning Strategies for ESL Vocabulary Acquisition," TESOL Q., vol. 25(4), pp. 655-670.

[5] D. M. D. Coyle, P. Hood, CLIL: Content and language integrated learning," Cambridge. Cambridge: Cambridge University Press, 2010. 
[6] G. Borg, Material Development for Foreign Language Teaching and Learning. Cambridge: Cambridge University Press, 2012.

[7] "http://unesdoc.unesco.org/images/0013/001325/132540e.pdf.".

[8] H. Nevilee, The Human Brain Processes Syntax in the Absence of Conscious Awareness. New York: Routledge, 1991.

[9] A. Wijaya, "Learning Material Evaluation and Try Out," TEFLIN J., vol. 122-133, no. 8(3), 2010.

[10] R. Li, The Process of Language Teaching and Learning Communicatively. New York: Routledge, 2004. 